\title{
The impact of nutrition and lifestyle on male fertility
}

\author{
Mahmoud Benatta ${ }^{1,2}$, Redha Kettache ${ }^{1,3}$, Noor Buchholz ${ }^{1}$, Alberto Trinchieri ${ }^{1}$ \\ ${ }^{1}$ U-merge Ltd. (Urology for Emerging Countries), London, UK. \\ 2 Department of Urology, Djilali Lyabes University Hospital, Sidi Bel Abbes, Algeria; \\ ${ }^{3}$ Department of Urology, EPH Bachir Bennacer, Biskra, Algeria.
}

\begin{abstract}
Summary Background and aims: Male unexplained infertility has long been suspected to result from environmental, lifestyle and nutritional factors. However, the literature on the subject is still scarce, and clinical studies providing robust evidence are even scarcer. In addition, some similar studies come to different conclusions. Dietary pattern can influence spermatogenesis by its content of fatty acids and antioxidants. Yet, in an age of industrialized mass food production, human bodies become more exposed to the ingestion of xenobiotics, as well as chemicals used for production, preservation, transportation and taste enhancement of foods. We attempted in this paper to collect the available evidence to date on the effect of nutritional components on male fertility. Material and methods: A systematic search of the relevant literature published in PubMed, ScienceDirect and Cochrane Central Register of Controlled Trials Database was conducted. Literature was evaluated according to the Newcastle-OttawaScale.

Results: Epidemiological observations are concordant in demonstrating an association of low-quality sperm parameters with higher intake of red meat, processed and organ meat and fullfat dairy. On the contrary, better semen parameters were observed in subjects consuming a healthy diet, rich in fruit, vegetables, whole grains and fish. Evidences of the negative impact on male fertility of by-products of water disinfection, accumulation in food chain of persistent organochlorine pollutants, pesticides, phthalates from food and water containers and hormones used in breeding cattle have been reported. Clinical trials of the effects of micronutrients on semen parameters and outcomes of assisted fertilization are encouraging, although optimal modality of treatment should be established.

Conclusions: Although quality of evidence should be ameliorat$e d$, it emerges that environmental factors can influence male fertility. Some nutrients may enhance fertility whereas others will worsen it. With diagnostic analysis on a molecular or even sub-molecular level, new interactions with micronutrients or molecular components of our daily ingested foods and leisure drugs may lead to a better understanding of so far suspected but as yet unexplained effects on male spermatogenesis and fertility.
\end{abstract}

KEY WORDS: Male fertility; Nutrients; Micronutrients; Dietary supplements; Lifestyle; Xenobiotics.

Submitted 13 April 2020; Accepted 20 April 2020

\section{INTRODUCTION}

Male infertility is attracting increasing interest due to its worldwide prevalence and the evidence of decline in semen quality of young health men (1). Prevalence of reported male infertility ranges from $2.5 \%$ to $12 \%$ with highest rates in Africa and Central/Eastern Europe (2). Rates of male infertility in North America, Australia, and Central and Eastern Europe varied from 4.5-6\%, 9\%, and $8-12 \%$, respectively. Male infertility is defined as the failure to achieve a pregnancy after 12 months or more of regular unprotected sexual intercourse as reported by couples or female partners of a couple.

Seminal quality is a prognostic factor of fertility which can be considered a proxy of male infertility although fecundity also depends from other couple-based covariates (3). Along the last 50 years a progressive decrease of the quality of the seminal parameters has been observed. A recent systematic review of 185 studies involving more than 40.000 men who provided semen analysis in the period 1973-2011 demonstrated a significant decline between 1973 and 2011 (4). This trend may arise from genetic, developmental and lifestyle factors. Particularly, involvement of nutritional factors has been highlighted by many studies

Cross-sectional population studies or case-control studies using food questionnaires evaluated the association of dietary patterns or quality of foods with seminal parameters (count, concentration, motility, morphology, DNA fragmentation) or with testis volume or sex hormone levels. In addition, some studies from fertility clinics considered more robust outcomes such as implantation rate, rate of clinical pregnancy and of live birth. Most of studies focused on the content of saturated fats that could have a negative impact on fertility or on the content of antioxidants and folates that could improve fertility. Molecular pathways of the effects of these nutrients in male fertility have been studied but they are not yet fully explained (Figure 1) (5-7).

Saturated fats are prevalent in animal-derived foods as red meat, processed meat and full-fat dairy product while fats from vegetable foods and fishes are polyunsaturated. Sperm cell are characterized by a high content of polyunsaturated fatty acids, as docosahexaenoic acid (DHA).

Concentrations of DHA with respect to saturated or trans fatty acids influence the melting point of plasmatic membrane, regulate the expression of peroxisome proliferatoractivated receptor gamma (PPARG), anti-apoptosis and hormone activity. Particularly, omega-3 PUFAs in fish are precursors of eicosanoids, which contribute to sperm

No conflict of interest declared. 
Figure 1.

Molecular pathways of the effects of fatty acids and antioxidants in sperm cell (negative effect in red, positive in green).

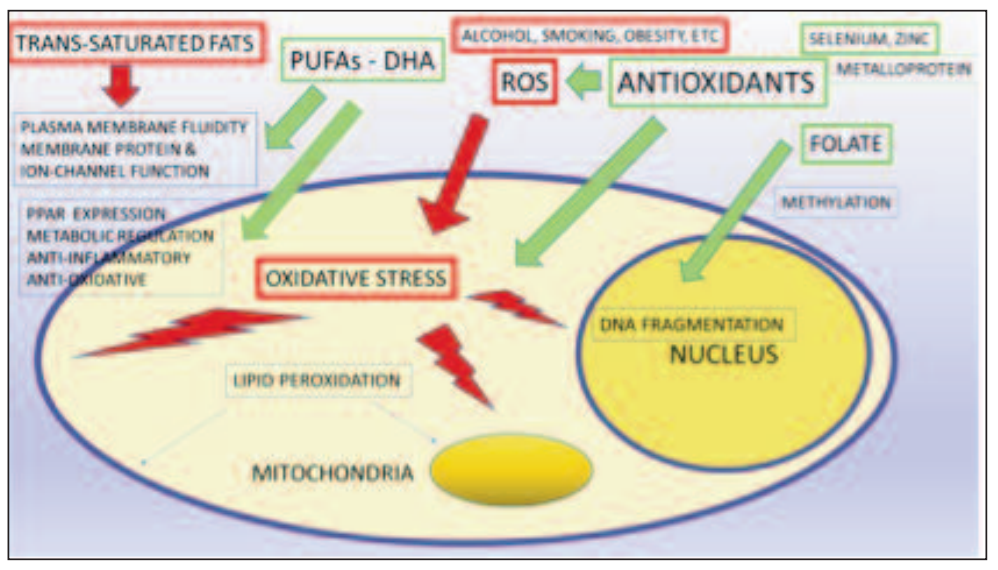

foods is difficult by using dietary questionnaires whereas more reliable results can be obtained by using biological markers to evaluate exposure to toxic substances.

The effects of the intake of some foods on seminal parameters can be biased by the concomitant effect of contamination. By example, it is difficult to differentiate the impact of consumption of vegetables from that of pesticides that are used in agriculture or the effect of red meat from that of residual hormones that could have been used in breeding or that of fish consumption by the risk of contamination from sea water pollution.

Finally, other information can be derived from the evaluation of the effect of the administration of dietary supplements to ameliorate seminal parameters of subfertile men attending fertility centres.

structure) and have a positive impact on testicular function. On the contrary, trans saturated fats interfere with the incorporation of long-chain polyunsaturated fatty acids into sperm membranes during epididymal maturation, and have a negative impact on testicular function, with reduction in total and free testosterone.

Antioxidants molecules, that are abundant in fruits and vegetables, have a positive effect on male fertility and in general on health conditions, by contrasting the activity of reactive oxygen species (ROS).

ROS (reactive oxygen species) show a biphasic effect on sperm cell function, because at physiological concentrations ROS from mitochondria have an important role in capacitation by activation of different intracellular mechanisms (high levels of cAMP, activating the PKA pathway, and leading to tyrosine phosphorylation). On the contrary, oxidative stress from excess ROS production causes peroxidation of lipids in the plasmatic membrane together with a damage of spermatic DNA. ROS have a negative effect on sperm motility by damaging plasmatic membrane and mitochondrial function.

Folates are involved in DNA synthesis and in methylation processes connected with protein synthesis. Folate deficiency causes instability and fragility of DNA by reducing availability of methylic groups that are a protection factor of DNA.

Other micronutrients are involved in the development of male infertility, as divalent cations such selenium, zinc or manganese that have a role in oxidative stress being incorporated in enzymes such as glutathione peroxidase or superoxide dismutase (8). Optimal levels are requested for spermiogenesis, whereas both deficiency and excess intake are associated with alterations of seminal parameters and serum testosterone levels.

In addition to the effects of nutrients, food intake can be associated to exposure to food-contaminating toxic substances or hormones that can have a relevant impact on male fertility. In an age of progressive industrialization, and moreover industrial mass food production using herbicides, pesticides, antibiotics, hormones, and chemicals to preserve and enhance the taste of heavily processed foods, these components can be absorbed into the human body. Evaluation of the effects of toxic contamination of
In this paper, we tried to review and summarize the available evidence on the topic. Our results are subdivided in two chapters describing review of epidemiological observations and clinical studies respectively.

\section{Methods}

A systematic search of the relevant literature published in PubMed, ScienceDirect and Cochrane Central Register of Controlled Trials Database was conducted. We reviewed separately epidemiological observations as reported in the literature and clinical trials with various nutritional components and their influence on male fertility.

For this reason, two separate searches (up to December 2018) were done using a combination of terms as both, Medical Subject Headings (MeSH) and keywords.

In the first search, male fertility-related keywords ("male fertility" OR "male infertility" OR "semen quality" OR "oligoasthenozoospermia" OR "sperm DNA fragmentation" OR "sperm DNA damage" OR "sperm aneuploidy" OR "Y chromosome") were used in combination with key words relating to food or nutrient ("food" OR "diet" OR "nutrition" OR "meat" OR "fish" OR "sugar" OR "vegetables" OR "fruits" OR "dairy" OR "genetically modified food" OR "alcohol" OR "pesticides"

\section{Figure 2.}

Systematic literature search 1.

\begin{tabular}{|r|c|}
\hline \multicolumn{2}{|c|}{ SEARCH FOR EPIDEMIOLOGY STUDIES } \\
\cline { 2 - 2 } \\
SCREENED & 103 \\
\cline { 2 - 2 } & 38 \\
SELECTED BY TILL AND ABSTRACT & 29 \\
RETRIEVED FROM REFERENCES & 67 \\
FULL-TEXT ASSESSED & 50 \\
INCWUDED & \\
\hline
\end{tabular}

Figure 3.

Systematic literature search 2.

\begin{tabular}{|r|c|}
\hline \multicolumn{2}{|c|}{ SEARCH FOR CLINICAL TRIALS } \\
\cline { 2 - 2 } SCREENED & 78 \\
\cline { 2 - 2 } SELECTED BY TILE AND ABSTRACT & 43 \\
RETRIEVED FROM REFERENCES & 14 \\
ASSESSED & 57 \\
INCLUDED & 19 \\
\hline
\end{tabular}


OR "hormone food contaminated" OR "tobacco" OR "cannabis") and combined with 'questionnaire' (Limit: Human, English). Reviews, clinical trials and case reports were excluded (Figure 2).

In the second search the same male fertility-related keywords were used in combination with key words relating to vitamin or micronutrient or herbal treatments ("selenium" OR "vitamin E" OR "coenzyme Q10" OR "zinc" OR "LCarnitine" OR "folic acid" OR "L Arginine" OR "herbal"). (Limit: Human, English). Only clinical trials were included (Figure 3).

The first search screened 103 studies, that were reduced to 38 after evaluation by title and abstract; 29 studies were retrieved by references of the selected studies; a total of 67 studies was assessed and 50 were included in the review. In the second search, the number of study screened, selected by title/abstract, retrieved by references, assessed and included were 79, 43, 14, 57 and 19 respectively.

Information extracted from each study was charted including: first author's last name; year of publication; number of subjects; food or nutrients or dietary pattern studied. Literature was evaluated using the NewcastleOttawa-Scale and evaluation forms. A narrative review of the data from the included studies was done.

\section{Results}

\section{Epidemiological observations}

Nutrition and lifestyle are considered by several authors as main factors in reproduction and fertility (9-11). Recent studies indicate that male obesity (12), as well as lifestyle factors as smoking and alcohol intake affect negatively the sperm quality (13).

Diet plays a key role in the improvement of sperm parameters, particularly the Mediterranean diet which is rich in omega 3 fatty acids, antioxidants and vitamins (vitamin E, vitamin C, beta-carotene, lycopene, cryptoxanthin, lutein) that all are associated with better semen

\section{Table 1.}

Vitamin, mineral and antioxidant intake and sperm quality.

\begin{tabular}{|c|c|c|c|c|}
\hline Author & Sample & Nutrient/food & $\begin{array}{l}\text { Effect on } \\
\text { semen quality }\end{array}$ & Parameters \\
\hline \multirow[t]{5}{*}{ Eskenazi et al. (2005) (14) } & $\begin{array}{l}97 \text { healthy } \\
\text { controls }\end{array}$ & Folate & No association & \\
\hline & & Zinc & No association & \\
\hline & & Vitamin C & Positive & $\begin{array}{l}\text { Sperm count ( } P-0.04) \text {, } \\
\text { Sperm concentration (million } / \mathrm{mL}) \\
\text { (P - 0.05) } \\
\text { Total progressively motile sperm count } \\
\text { (million/mL) }(P-0.09)\end{array}$ \\
\hline & & Vitamin E & Positive & $\begin{array}{l}\text { Progressive sperm motility }(\%) \\
\text { (P - 0.04) } \\
\text { Total progressively motile sperm count } \\
\text { (million/mL) }(P<0.05)\end{array}$ \\
\hline & & $\beta$-carotene & Positive & $\begin{array}{l}\text { Sperm concentration (million } / \mathrm{mL} \text { ) } \\
\text { (P- } 0.06) \\
\text { Progressive motility }(P-0.06)\end{array}$ \\
\hline \multirow[t]{3}{*}{ Mendiola 2010(15) } & $\begin{array}{l}31+30 \\
\text { men of couples } \\
\text { attending a } \\
\text { fertility clinic } \\
\text { without/with } \\
\text { poor semen } \\
\text { quality }\end{array}$ & Folate & Positive & Semen quality \\
\hline & & Vitamin C & Positive & Semen quality \\
\hline & & Lycopene & Positive & Semen quality \\
\hline \multirow[t]{4}{*}{ Minguez-Alarcón 2012 (16) } & $\begin{array}{l}215 \\
\text { healthy controls } \\
\text { (university } \\
\text { students) }\end{array}$ & Cryptoxanthin & Positive & Total motile sperm count $P$ trend -0.03 \\
\hline & & Vitamin C & Positive & $\begin{array}{l}\text { Total motile sperm count } P \text { trend }=0.04 \\
\text { Semen volume } P \text { trend }=0.04\end{array}$ \\
\hline & & Lycopene & Positive & Total motile sperm count $P$ trend -0.03 \\
\hline & & $\beta$-carotene & Positive & Total motile sperm count $P$ trend -0.04 \\
\hline \multirow[t]{4}{*}{ Zareba $2013(17)$} & $\begin{array}{l}189 \\
\text { healthy controls } \\
\text { (university } \\
\text { students) } \\
\end{array}$ & $\beta$-carotene & Positive & Progressive motility \\
\hline & & Lutein & Positive & Progressive motility \\
\hline & & Lycopene & Positive & Sperm morphology \\
\hline & & Vitamin C & $\begin{array}{l}\text { Nonlinear } \\
\text { relationship }\end{array}$ & $\begin{array}{l}\text { Sperm concentration } \\
\text { (second quartile highest sperm } \\
\text { concentrations top quartile of intake lowest } \\
\text { concentrations) }\end{array}$ \\
\hline
\end{tabular}


Table 2.

Dietary patterns and sperm quality.

\begin{tabular}{|c|c|c|c|c|}
\hline Author & Sample & Dietary pattem & $\begin{array}{l}\text { Effect on } \\
\text { semen quality }\end{array}$ & Parameters \\
\hline \multirow[t]{2}{*}{ Wujhonic $2009(20)$} & $\begin{array}{l}161 \\
\text { men from subiertile } \\
\text { couples }\end{array}$ & $\begin{array}{l}\text { Health Conscious } \\
\text { dietary pattem } \\
\text { (high intakes of fruits, } \\
\text { vegetables, fish and whole } \\
\text { grains) }\end{array}$ & Positive & ONA fragegmentation index (DFl) \\
\hline & & $\begin{array}{l}\text { Traditional Dutch } \\
\text { dietary pattem } \\
\text { (high intakes of meat, } \\
\text { potatoes and whole grains } \\
\text { and low intakes of } \\
\text { beverages and sweets. }\end{array}$ & Positive & Sperm concentration \\
\hline \multirow[t]{2}{*}{ Gashins 2012 (21) } & $\begin{array}{l}188 \\
\text { healthy controls } \\
\text { (university students) }\end{array}$ & $\begin{array}{l}\text { 'Western' pattem } \\
\text { (high intake of red and } \\
\text { procsssed meat, refined } \\
\text { grains, pizza, snecks, high- } \\
\text { energy drinks and sweets) }\end{array}$ & No association & \\
\hline & & $\begin{array}{l}\text { 'Prudent' pattem } \\
\text { (high intake of fish, } \\
\text { chicken, frutt, vegetables, } \\
\text { legumes and whole grains) }\end{array}$ & Positive & $\begin{array}{l}\text { Percent progressively motila sperm in } \\
\text { multivariate models ( } P \text { trend }-0.04)\end{array}$ \\
\hline \multirow[t]{2}{*}{ Cutiles -Talin 2015 (22) } & $\begin{array}{l}215 \\
\text { healthy controls } \\
\text { (university students) }\end{array}$ & $\begin{array}{l}\text { Mediterranean pattern } \\
\text { (high intakes of } \\
\text { vegetables, fruits and } \\
\text { sesiood) }\end{array}$ & Positive & Total sperm count ( $P$ trend $=0.04)$ \\
\hline & & $\begin{array}{l}\text { Western pattern } \\
\text { (high intakes of processed } \\
\text { meats, } \\
\text { French fries and snacks) }\end{array}$ & Positive & $\begin{array}{l}\text { Morphologically normal sperm \&, } \\
\text { (P trend }-0.008 \text { ) }\end{array}$ \\
\hline \multirow[t]{4}{*}{ Liv 2015 (23) } & $\begin{array}{l}7282 \\
\text { subjects attending } \\
\text { medical screening } \\
\text { program }\end{array}$ & Western diet & Negative & $\begin{array}{l}\text { Sperm concentration } P<0.001 \\
\text { Sperm morphology } P<0.001\end{array}$ \\
\hline & & $\begin{array}{l}\text { High swoet snacks \& } \\
\text { sugar-sweetened drinks }\end{array}$ & Negative & Sperm concentration $P=0.001$ \\
\hline & & High-cartohydrate diet & Negative & $\begin{array}{l}\text { Total sperm motility } P=0.012 \\
\text { Progressive sperm motility } P=0.025\end{array}$ \\
\hline & & High-sodium diet. & Negative & Sperm morphology $P=0.035$ \\
\hline Jurewicz 2016 (24) & $\begin{array}{l}336 \\
\text { men attending infertility } \\
\text { clinic }\end{array}$ & $\begin{array}{l}\text { Prudent pestern } \\
\text { (high intakes of fish, } \\
\text { chicken, fruit, cruciferous } \\
\text { vegetables, tomatoes, } \\
\text { leafy green vegetables, } \\
\text { legumes, and whole } \\
\text { grains) versus } \\
\text { Western pattem } \\
\text { (high intakes of red and } \\
\text { processed meat, butter, } \\
\text { high-fat dairy, refined } \\
\text { grains, pizza, snocks, } \\
\text { highenergy drinks, } \\
\text { mayonnaise, and sweets) }\end{array}$ & Positive & $\begin{array}{l}\text { Sperm concentration }(P-0.05) \\
\text { Level of testosterane (P-0.03) } \\
\text { Decreased ONA fragmentation index } \\
(P=.05) \\
\text { Seme parameters }\end{array}$ \\
\hline
\end{tabular}

quality parameters (Table 1) (14-18). A better compliance with Mediterranean diet was found to be associated with better semen quality parameters (sperm concentration, count, and motility) (19).

Similarly, in non-Mediterranean Countries, the so called "Prudent" or "Health Conscious" diets, involving high intakes of fruits, vegetables, legumes, fish and whole grains, were related to better sperm quality than "Western" diet that is rich in red and processed meat, refined grains, high-energy drinks and sweets (Table 2) (20-24). Higher intakes of seafood, poultry, whole grains, fruits and vegetables have been consistently associated with better semen parameters in a wide range of studies in North America, Europe, the Middle East and East Asia. (Table 3) (10, 19-27). A recent review concluded that diets rich in red and processed meats, potatoes, sweets and sweetened beverages were associated with decreased quality of semen parameters whereas higher intakes of fruits and vegetables, whole grains, seafood and poultry had the opposite effect (34). Soy foods have been inversely associated with the quality of semen in some studies (35) although soy food intake in men was not related to outcomes of in vitro fertilization in couples undergoing infertility treatment (36).

The intake of trans and saturated fats has been related to poor semen quality. Trans-saturated fat intake has also been related to other markers of poor testicular function, such as lower testosterone and lower testicular volume (37-40) (Table 4). On the contrary, omega-3 polyunsaturated fats were associated with better seminal parameters and testicular volume $(37,40)$. 
Table 3.

Foods and sperm quality.

\begin{tabular}{|c|c|c|c|c|}
\hline Auther & Sample & Foods & $\begin{array}{l}\text { Effect on } \\
\text { semen quality }\end{array}$ & Parameters \\
\hline \multirow[t]{2}{*}{ Merdats 2009 (25) } & $\begin{array}{l}\text { 31-30 } \\
\text { ner af couplas atterding a } \\
\text { fertly clinis vithout/with } \\
\text { pcor semen cualty }\end{array}$ & $\begin{array}{l}\text { Lethute and } \\
\text { sanzatoes, fraits } \\
\text { (apricots and } \\
\text { pesches) }\end{array}$ & Fositve & $\begin{array}{l}\text { Comparisan of nen with posr sanen quzlity } \\
\text { and namospernic cantrols }\end{array}$ \\
\hline & & $\begin{array}{l}\text { Dainy and neat } \\
\text { grocessed groducts }\end{array}$ & Nefative & $\begin{array}{l}\text { Companisan of nen with posr senen qualiay } \\
\text { and namospernic cantro's }\end{array}$ \\
\hline \multirow[t]{3}{*}{$\begin{array}{l}\text { Maldansto Carceles } \\
2019 \text { (26) }\end{array}$} & $\begin{array}{l}206 \text { heal:hy controls } \\
\text { (aniversity students) }\end{array}$ & To:al meat & Ma assaciatian & \\
\hline & & Shellist & Fositas & Pr:gressive mo:liky p tusnd $\leq 0.001$ \\
\hline & & 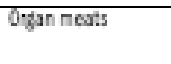 & Nafzative & 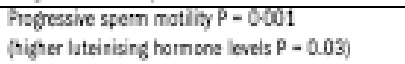 \\
\hline \multirow[t]{6}{*}{$\begin{array}{l}\text { Eslanian ef } \mathrm{R} . \\
(2012)(27)\end{array}$} & 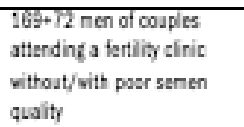 & Frocessed meat & Mefative & $\begin{array}{l}\text { Valane, spem consertration, matility and } \\
\text { narphsiag } \\
\text { Higher risk of asthenasosspemis CA } 203\end{array}$ \\
\hline & & Sozets intake & Nafative & 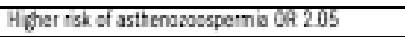 \\
\hline & & $\begin{array}{l}\text { Dark foten } \\
\text { vefotaties }\end{array}$ & Fositas & Lowar risk of asthenswoespernia f trend - 0.01 \\
\hline & & $\sin m i k$ & Fositas & 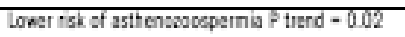 \\
\hline & & Foulty & Fusitas & Lowar risk of asthensovoepermis P therd - 0.03 \\
\hline & & Sev foos & Fusitas: & 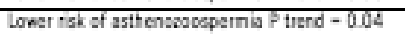 \\
\hline \multirow[t]{3}{*}{ Bragio 2012(10) } & 250 men anderfoing |CS| & Fuit: 6 atereas & Fosit:ve & Spern natisty \\
\hline & & Ted neat & Nefative & $\begin{array}{l}\text { Implantabon rate } \\
\text { Pregrancy chance }\end{array}$ \\
\hline & & We bुht loes diat & Nefative & $\begin{array}{l}\text { Implantzion rats } \\
\text { Pregrancy chance }\end{array}$ \\
\hline \multirow[t]{2}{*}{ Afeiche $2023(28)$} & $\begin{array}{l}\text { I8פ haslity controls } \\
\text { (ariversity students) }\end{array}$ & Totaldairy faods & Mafative & Narnal spem mo:phology 6 p tsend 0.004 \\
\hline & & Ful fat dan back & Nefative & 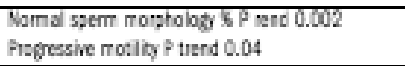 \\
\hline Afeche $2014(29)$ & $\begin{array}{l}\text { I8: healihy controls } \\
\text { (ariversity students) }\end{array}$ & Lon sat dairy food & Fositas & Pragressive moting $(k)$ p send -0.03 \\
\hline Afeche $2014(30)$ & $\begin{array}{l}\text { I8פ haslihy controls } \\
\text { (aniversity students) }\end{array}$ & Pracessed nod neot: & Nefative & $\begin{array}{l}\text { Total spern cant F trend - } 0.01 \\
\text { Esosalate valune }(\mathrm{ml}) \mathrm{P} \text { trend }-0.003\end{array}$ \\
\hline Afache $2014(\mathrm{~d} 1)$ & $\begin{array}{l}155 \text { men af co:ples } \\
\text { attending fertility certer }\end{array}$ & Fist intake & Fositas: & $\begin{array}{l}\text { Narnal norptolod f trend - } 0.01 \\
\text { Spem caunt } P \text { trend - } 0.005\end{array}$ \\
\hline Chiv $(2014)(32)$ & $\begin{array}{l}\text { I89 haslihy controls } \\
\text { (aniversity students) }\end{array}$ & $\begin{array}{l}\text { Sudat sweatered } \\
\text { beverzge }\end{array}$ & Safative & Spern matility (N) \\
\hline \multirow[t]{3}{*}{ Chv $(2015)(33)$} & $\begin{array}{l}155 \mathrm{men} \text { af cosples } \\
\text { atterding fertility certer }\end{array}$ & $\begin{array}{l}\text { Total frut } \mathrm{B} \\
\text { vegetaties }\end{array}$ & No assaciatian & Serren quality parzmetats \\
\hline & & $\begin{array}{l}\text { Hob pesticice } \\
\text { nesidas frait and } \\
\text { vegetatie intake }\end{array}$ & Nefative & 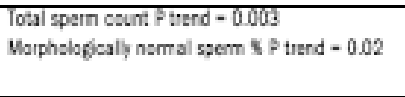 \\
\hline & & $\begin{array}{l}\text { Lon 5a-noderabe } \\
\text { gesticida nesidae } \\
\text { fut and vetatzble } \\
\text { intaks }\end{array}$ & Fusitve & Marphelagealy nambil spem P trend - 0.04 \\
\hline Chavamo $2080(35)$ & 99 nan of sabfertla cauples & Soy bad & Safative & Sperm corcentratin \\
\hline 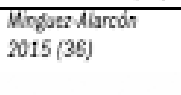 & $\begin{array}{l}184 \text { men af cosples } \\
\text { attending fertiliky center }\end{array}$ & Soy bouts & Ka assaciatian & 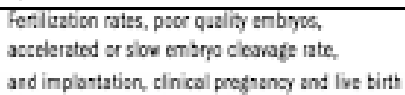 \\
\hline
\end{tabular}

Critical appraisal of this evidence highlights some possible limitations. In most cross-sectional studies populations were numerically limited and not always representative of the general population. Many studies were performed on volunteers recruited among university students aged 18 to 23 years, whereas other studies considered men from couples who attended fertility clinics. Translation of these results to the general population might be questionable. Only a few studies have been carried out in numerically consistent populations representing the general population $(23,38)$. Similarly, case-con- trol studies were performed by comparing the dietary intakes of men from couples attending fertility clinics with and without alterations of seminal parameters.

\section{Alcohol and caffeine}

Alcohol induces testicular atrophy and alterations of Leydig and Sertoli cells and decrease luteinizing hormone (LH) and follicle-stimulating hormone (FSH) levels (41).

Daily consumption of alcohol affects sperm quality and decreases ejaculate volume, sperm counts, and sperm motility. Comparing the sperms of 66 "alcoholic" men to 
Table 4.

Dietary fats and semen quality.

\begin{tabular}{|c|c|c|c|c|}
\hline Author & Sample & Nutrient/Food & $\begin{array}{l}\text { Effect on } \\
\text { semen quality }\end{array}$ & Parameters \\
\hline \multirow[t]{4}{*}{ Altanuo ef al. $(2012)(37)$} & $\begin{array}{l}99 \text { mala partoners } \\
\text { ton infertila } \\
\text { couples }\end{array}$ & Totalfat & Mefative & $\begin{array}{l}\text { To:al spern count } \\
\text { and spern (P trend }-0.01\rangle\end{array}$ \\
\hline & & Sabusted bit & Kefative (NS) & Spetn levets $(r-0.09)$ \\
\hline & & Onepis 3 polfunsaturated fosts & Fositas & $\begin{array}{l}\text { Satustated fot intake kas unrelabod is spem } \\
\text { levels }(r-0.09)\end{array}$ \\
\hline & & & & Narnal norptolos ate (P trenc) - 0.02) \\
\hline Jensen $2013(34)$ & $\begin{array}{l}701 \text { men from } \\
\text { genteral population }\end{array}$ & 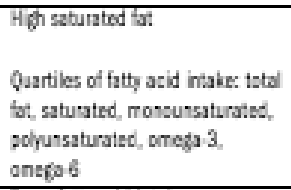 & Mefative & $\begin{array}{l}\text { Spetm corcentratisn } \\
\text { Total sperm count } \\
\text { Na assacistian between semen quaity and } \\
\text { intake of ather types of fat was found }\end{array}$ \\
\hline \multirow[t]{2}{*}{ Crunamo $2014(38)$} & $\begin{array}{l}209 \text { hality } \\
\text { controls (university } \\
\text { sudents) }\end{array}$ & Trans tot:y acis intzke & Nefative & To:al spatm count (P thend - 0.03) \\
\hline & & Cholesterol & Nafative & Eocalate valune (P trens -0.04$)$ \\
\hline \multirow[t]{4}{*}{ Minguez Alamoin 2017 (39) } & $\begin{array}{l}\text { 20: hasithy } \\
\text { controls (university } \\
\text { students) }\end{array}$ & Manoursaturated forty acisa & Mequative & $\begin{array}{l}\text { Froe tasiastertona, botal bestostanore, } \\
\text { and inhbin B }\end{array}$ \\
\hline & & Trans boty aciss & Mefative & 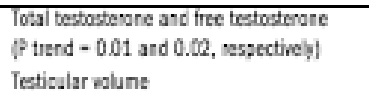 \\
\hline & & $\begin{array}{l}\text { Onepe } 3 \text { polfunsatursted forty } \\
\text { asids }\end{array}$ & Pesinge & Testisular valune \\
\hline & & $\begin{array}{l}\text { Onefe } 6 \text { golyunsaturated forty } \\
\text { asids }\end{array}$ & Mefative & Testisular valune (hipher LH) \\
\hline
\end{tabular}

those of 30 "non-alcoholic" men, there was a significant decrease in sperm count, progressive mobility, and vitality (42). Chronic high consumption of alcohol (more than $60 \mathrm{~g}$ per day or 6 glasses of wine) can lead to azoospermia (43). There is a significant inverse relationship between alcohol consumption and sperm concentration, sperm count and percentage of typical spermatozoids. Stopping consumption would restore normal spermatogenesis and azoospermia secondary to alcohol (44).

A meta-analysis confirmed that alcohol has a detrimental effect on semen parameters although spermatogenesis seemed to be not affected by a moderate consumption (45). Another meta-analysis of the effects of alcohol on in vitro fertilization (IVF) showed that live birth rates are significantly reduced when humans consume alcohol even in lower doses in the month or even the week before attempted fertilization. Excessive consumption of alcohol must be avoided in humans during the attempted medical assisted fertilization, but a moderate consumption (one or two glasses of wine per day) might also have an opposite effect on the spermatic characteristics and the results of the medical assisted procreation attempt (46). A systematic review of the effects of coffee and caffeine intake on semen parameters found inconsistent evidences and conflicting results, although some studies showed a possible association with sperm DNA damage (47).

\section{Food and water contamination}

Most of the literature on the effect of water and food contaminants on male infertility is derived from experimental

Table 5.

Water and food contaminants and male infertility.

\begin{tabular}{|c|c|c|c|}
\hline $\begin{array}{l}\text { Contaminant } \\
\text { Trihalomethanes } \\
\text { and haloacetic acids }\end{array}$ & $\begin{array}{l}\text { Source } \\
\text { By products of water disinfection }\end{array}$ & $\begin{array}{l}\text { Mechanism } \\
\text { Interaction of disinfecting agents } \\
\text { (chlorine and ozone) with naturally } \\
\text { occurring substances in the water }\end{array}$ & $\begin{array}{l}\text { Epidemiological data \& markers of exposure } \\
\text { Urinary trichloroacetic acid associated with lower sperm concentrations } \\
\text { Serum trihalomethane levels conflicting results }\end{array}$ \\
\hline $\begin{array}{l}\text { Persistent organocholorine } \\
\text { pollutants (POPs) }\end{array}$ & $\begin{array}{l}\text { Pesticides } \\
\text { industrial chemicals solvents }\end{array}$ & $\begin{array}{l}\text { Accumulation in food chain with } \\
\text { animal sources (particularly fish) }\end{array}$ & $\begin{array}{l}\text { Serum polychlorinated biphenyl (PCB) metabolite levels associated with lower sperm } \\
\text { concentrations } \\
\text { Several POPS associated with lower sperm count } \\
\text { CB-153 and p,p'-DDE levels associated with lower sperm count (conflicting results) }\end{array}$ \\
\hline Pesticides & Agriculture & $\begin{array}{l}\text { Dietary consumption } \\
\text { (transcutaneous absorption } \\
\text { and inhalation) }\end{array}$ & $\begin{array}{l}\text { Organophosphate metabolites were found to be negatively associated with total } \\
\text { sperm counts }\end{array}$ \\
\hline Phthalates & $\begin{array}{l}\text { Plasticizers in consumer } \\
\text { and personal care products }\end{array}$ & $\begin{array}{l}\text { Dietary contamination by food } \\
\text { and water containers }\end{array}$ & $\begin{array}{l}\text { Urinary dibutyl phthalate (DBP) associated with higher serum estradiol levels } \\
\text { and estradiol: testosterone ratio, lower serum testosterone levels and sperm counts } \\
\text { (most but not all studies) } \\
\text { Urinary monobutyl phthalate (MBP) associated with decreased sperm counts }\end{array}$ \\
\hline
\end{tabular}


animal studies or studies of acute occupational exposure. Evidence of the effects in the general population of chronic low-dose exposures is limited because of the complexity of the design of the studies. Levels of biological markers of exposure have been correlated with seminal and hormone parameters in general population. Available data has been reviewed by Gabrielsen and Tanrikut (8). In Table 5 we summarized evidences about water and food contaminants that could affect male fertility.

Food contaminants often induce endocrine disorders, as in the case of commonly used glyphosate-based herbicides that act as a disruptor of mammalian cytochrome P450 aromatase activity from concentrations 100 times lower than the recommended use in agriculture and can also affect aromatase gene expression (48). Endocrine disorders can also be induced by the presence of residual hormones in red meat and processed meat. In some countries anabolic sex steroids are administered to cattle for growth promotion resulting hormone residues in beef. Although the possible biological significance of very low levels of estradiol is neglected, residual hormones are one possible explanation of lower semen quality parameters observed in consumers of processed or red meat (49). On the other hand, maternal beef consumption, and possibly xenobiotics in beef may alter testicular development in utero and adversely affect offspring reproductive capacity (50). Despite a lack of human studies, a link between infertility and genetically modified foods (GMF) has been postulated although GMF-related infertility seems to affect women more than men (51).

\section{Tobacco}

Smokers have an unusually high concentration of heavy metals in the seminal fluid, such lead and cadmium that are negatively correlated with sperm concentration, mobility and morphology (52). On the other hand, high levels of trans-3'-hydroxycotinine (3HC), a metabolite of nicotine, in seminal fluid are correlated with a decreased sperm mobility (53). The seminal plasma analysis of smokers shows a significantly higher proportion of inflammatory proteins. In fact, smoking seems associated with an inflammatory state of the accessory glands, which would eventually cause an alteration of the functional quality of spermatozoids, a decrease of acrosome integrity and mitochondrial activity, and an increased DNA fragmentation (54). Sperm concentration, total motility, and the number of typical spermatozoids is reduced in smokers (55).

Tobacco also affects the intrinsic quality of spermatozoids. The analysis of the degree of fragmentation of sperm DNA showed a significantly higher fragmentation of DNA in smokers than in non-smokers (32\% against 25.9\%) (56). In an in-vitro fertilization trial, smoking among men was significantly and positively correlated with an increased risk of early spontaneous abortion $(\mathrm{OR}=2.2)(57)$.

Paternal smoking can also influence the health of newborns by transmission of DNA damaged by oxidative stress. Alterations of the methylation of sperm DNA in male smokers are compatible with alterations observed in their offspring (58). In addition, de-novo mutations in paternal spermatozoids induced by smoking can be transmitted (59).

\section{Cannabis}

After consumption of cannabis, its metabolites are found in the seminal fluid, and spermatozoa are thus exposed during their passage through the epididymis (60). Cannabis interferes with spermatogenesis by central and peripheral mechanisms. The stimulation of receptors coupled to G protein inhibits adenylate cyclase levels decreasing cAMP levels in testicular tissue, spermatozoa, and hypothalamus. Cannabis blocks the hypothalamic release of GnRH and the anterior pituitary production of LH. Furthermore, it reduces the release of testosterone from Leydig cells via specific receptors (61).

In a large sample of the general male population of Denmark, there was a significant negative correlation between cannabis consumption and sperm concentration, count, and mobility. In case of regular exposure to cannabis (9 to 18 cannabis joints a week) a decrease in sperm concentration was observed with a significant negative correlation between the amount of cannabis consumed and the sperm count. Chronic and intensive use of cannabis (more than 10 cannabis joints per week) was also associated with an alteration of Leydig cell function resulting in a significant dose-dependent decrease in testosterone serum levels (62). In conclusion, cannabis use should be considered as a potential cause of alteration of spermatogenesis or a co-factor aggravating preexisting spermatogenesis disorders.

\section{Obesity}

Obesity is related to excessive intake of food and reduced physical activity. Oligospermia is more frequent in obese men and in obesity an increase in DNA fragmentation was also described (63). Multiple interdependent mechanisms contribute to the negative effect of obesity on male fertility (64). Obesity is associated to alterations of the hypothalamic-pituitary axis because of various endocrine mechanisms such as production of estrogens by aromatization of testicular and adrenal androgens in excess adipose tissue, leptin resistance at kisspeptin neurons, and excessive production of endogenous opioids, leading to hypogonadotropic hyper-estrogenic hypogonadism. A significant decrease in free and total testosterone levels and a significant increase in estrogen levels are resulting, both contributing to alteration of spermatogenesis. The decrease in serum testosterone concentration is significantly associated with insulin resistance and a lower volume of ejaculate (65). Furthermore, obesity may directly alter spermatogenesis by its action on Sertoli cells, as suggested by the more severe decrease in inhibin B levels compared with the decrease in FSH. Finally, an increase in scrotal temperature caused by excessive testicular warming in the seated position may negatively affect spermatogenesis.

\section{Clinical trials}

Several interventional studies evaluated the effect of dietary supplementation on semen parameters of subfertile men or outcomes of assisted fertilization. Oral supplements include coenzyme Q10, L-Carnitine, vitamins, zinc and other antioxidants.

Coenzyme 210

A significant improvement of spermatogenesis was evi- 
dent with coenzyme Q10 therapy. Mean sperm concentration, sperm progressive motility, and rate of sperm with normal morphology improved significantly after 12 month of coenzyme Q10 therapy (66). A positive correlation was found between duration of Q10 treatment duration and sperm count, motility and morphology (67). Even the reduced form of coenzyme Q10 (ubiquinol) was significantly effective in men with unexplained oligoasthenoteratozoospermia (68).

\section{L-Carnitine}

L-Carnitine (LC) together with acetyl-L-Carnitine (LAC) are commonly used because of their ability to improve sperm quality and pregnancy rate in males suffering from asthenoteratozoospermia (69). LC and LAC improve the total oxyradical scavenging capacity of the seminal fluid (70) and prevent DNA oxidation of human spermatozoa (71). Treatment with LC increased the success rate of intracytoplasmic sperm injection (ICSI) (72). In a doubleblind randomized controlled trial, a combination of LC and coenzyme Q10 increased sperm motility and rate of progressively motile sperm more than LC or coenzyme Q10 alone or than In the control group. The percentage of sperm DNA fragments was markedly low and the rate of clinical pregnancy was remarkably higher in the combination group than in controls (73).

\section{Vitamin $E$}

Levels of vitamin $\mathrm{E}$ in seminal plasma are related to sperm motility (74). Accordingly, lower levels of vitamin E were observed in the semen of infertile men (75). A prospective, multi-centered, randomized controlled study reported that vitamin E can improve sperm concentration, percentage of progressively motile sperm, and rate of natural pregnancies (76).

\section{Zinc and folic acid}

The zinc concentration of seminal plasma is significantly higher in fertile men in comparison to subfertile men (77). In a study, supplementation with zinc sulphate and folic acid did not ameliorate sperm functional parameters in oligoasthenoteratozoospermic men (78), whilst in another double-blind, placebo-controlled interventional study the total normal sperm count increased after a combined zinc sulfate and folic acid treatment in both subfertile and fertile men (79).

\section{Combination treatment}

A double-blind placebo-controlled study (80) using supplementation of L-carnitine, fumarate, acetyl-L-carnitine, Fructose, CoQ10, vitamin C, zinc, folic acid and vitamin B12 reported an increase of sperm concentration, total motility and pregnancy rate in couples whose males had varicocele or not. No difference of semen volume and not significant improvement of progressive motility were observed. Another double-blind, multi-center, randomized controlled trial showed that a combination of antioxidants and vitamins (vitamin C, vitamin D3, vitamin E, folic acid, zinc, selenium, L-carnitine) did not improve semen parameters or DNA fragmentation in infertile men (81). An evidence-based review of randomized trials concluded that antioxidant supplements are beneficial in improving semen quality and clinical pregnancy rates for men from couples undergoing infertility treatment (82). More recent meta-analyses confirmed the positive results of the administration of antioxidants in subfertile men, although the poor quality of the studies considered in their analyses was highlighted.

A Cochrane meta-analysis considered 61 randomized clinical trials (RCTs) with a total population of 6000 subfertile men of couples attending a reproductive clinic to evaluate the effect of the oral administration of a wide range of 18 antioxidants on assisted reproductive techniques outcomes pregnancy or live birth rate (83).

Only few small studies reported on pregnancy or live birth rate. Use of antioxidants increased, the chance of clinical pregnancy from an estimated baseline of $7 \%$ following placebo or no treatment to a $12 \%$ to $26 \%$ rate after antioxidants $(\mathrm{OR}=2.97)$. Live birth rate after antioxidants ranged between 14 and 26\% whereas a $12 \%$ rate was observed after placebo or no treatment $(\mathrm{OR}=1.79)$.

Most studies were rated as 'low' to 'very low' quality with high heterogeneity and serious risk of bias (poor reporting of methods of randomisation, unclear or high attrition, low event rates and small sample sizes).

In another meta-analysis of 7 studies (84) a significant improvement of semen parameters (count, motility, morphology) was shown after administration of selenium (200 $\mu \mathrm{g} /$ day and $100 \mu \mathrm{g} /$ day), combination of ), L-carnitine (2 g/day) and acetyl-L-carnitine (LAC; $1 \mathrm{~g} /$ day) and co-enzyme Q10 (200 and $300 \mathrm{mg} /$ day). Information of the effect on pregnancy rate was not obtained because it was evaluated in a limited number of trials. The systematic review of other trials identified promising results for supplementation with zinc combined with folic acid, eicosapentaenoic acid and docosahexaenoic acid.

\section{Phytotherapeutica}

A poly-herbal formulation (a combination of the roots of Chlorophytum borivilianum, seeds of Mimosa pudica, sap of Acacia Senegal, root of Astragalus membranaceus, seed coat of Plantago ovate, sap of Bombax ceiba, root of Eurycoma longifolia and rocky candy) was tested for its effect on the spermatogenic potential in oligospermic patients. After 90 days, there was a 256\% increase in sperm concentration, a $154 \%$ increase in semen volume and a $215 \%$ increase in sperm motility, respectively (85).

\section{References}

1. Winters BR, Walsh TJ. The epidemiology of male infertility. Urol Clin North Am. 2014; 41:195-204.

2. Agarwal A, Mulgund A, Hamada A, Chyatte MR. A unique view on male infertility around the globe. Reprod Biol Endocrinol. 2015; 13:37.

3. Levine H, Jergensen N, Martino-Andrade A, et al. Temporal trends in sperm count: a systematic review and meta-regression analysis. Hum Reprod Update. 2017; 23:646-659.

4. Buck Louis GM, et al. Semen quality and time to pregnancy: the Longitudinal Investigation of Fertility and the Environment Study. Fertil Steril. 2014; 101:453-62.

5. Aksoy Y, Aksoy H, Altinkaynak K, et al. Sperm fatty acid compo- 
sition in subfertile men Prostaglandins Leukot Essent Fatty Acids. 2006; 75:75-9.

6. Esmaeili V, Shahverdi AH, Moghadasian MH, Alizadeh AR. Dietary fatty acids affect semen quality a review Andrology. 2015; 3:450-461.

7. Martin-Hidalgo D, Bragado MJ, Batista AR, et al. Antioxidants and male fertility: from molecular studies to clinical evidence. Antioxidants (Basel) 2019; 8(4). pii: E89.

8. Gabrielsen JS, Tanrikut C. Chronic exposures and male fertility: the impacts of environment, diet, and drug use on spermatogenesis. Andrology. 2016; 4:648-61.

9. Giahi L, Mohammadmoradi S, Javidan A, Sadeghi MR. Nutritional modifications in male infertility: a systematic review covering 2 decades. Nutr Rev. 2016; 74:118-30.

10. Braga DP, Halpern G, Figueira RC, et al. Food intake and social habits in male patients and its relationship to intracytoplasmic sperm injection outcomes. Fertil Steril. 2012; 97:53-59.

11. Salas-Huetos A, Bulló M, Salas-Salvadó J. Dietary patterns, foods and nutrients in male fertility parameters and fecundability: a systematic review of observational studies. Hum Reprod Update. 2017; 23:371-389.

12. Kahn BE, Brannigan RE Obesity and male infertility Curr Opin Urol. 2017; 27:441-445.

13. Bendayan $M$, Alter L, Swierkowski-Blanchard $N$, et al. Environment and lifestyle: Impacts on male fertility? Gynecol Obstet Fertil Senol. 2018; 46:47-56.

14. Eskenazi B, Kidd SA, Marks AR, et al. Antioxidant intake is associated with semen quality in healthy men. Hum Reprod 2005; 20:1006-1012

15. Mendiola J, Torres-Cantero AM, Vioque J, et al. A low intake of antioxidant nutrients is associated with poor semen quality in patients attending Fertility Clinics.Fertil Steril 2010; 93:1128-1133.

16. Mínguez-Alarcón L, Mendiola J, López-Espín JJ, et al. Dietary intake of antioxidant nutrients is associated with semen quality in young university students. Hum Reprod 2012; 27:2807-2814.

17. Zareba $P$, Colaci DS, Afeiche $M$, et al. Semen quality in relation to antioxidant intake in a healthy male population. Fertil Steril. 2013; 100:1572-1579.

18. Valk E, Hornstra G. Relationship between vitamin E requirement and polyunsaturated fatty acid intake in man: a review. Int $J$ Vitam Nutr Res. 2000; 70:31-42.

19. Karayiannis D, Kontogianni MD, Mendorou C, et al. Association between adherence to the Mediterranean diet and semen quality parameters in male partners of couples attempting fertility.Hum Reprod. 2017; 32:215-222.

20. Vujkovic M, de Vries JH, Dohle GR, et al. Associations between dietary patterns and semen quality in men undergoing IVF/ICSI treatment. Hum Reprod. 2009; 24:1304-1312.

21. Gaskins AJ, Colaci DS, Mendiola J, et al. Dietary patterns and semen quality in young men. Hum Reprod. 2012; 27:2899-2907.

22. Cutillas-Tolín A, Mínguez-Alarcón L, Mendiola J, et al. Mediterranean and western dietary patterns are related to markers of testicular function among healthy men. Hum Reprod. 2015; 30:2945-2955

23. Liu CY, Chou YC, Chao J, et al. The association between dietary patterns and semen quality in a general sian population of 7282 males. PLOS ONE 2015; 10:e0134224.

24. Jurewicz J, Radwan M, Sobala W, et al. Dietary patterns and their relationship with semen quality. Am J Mens Health. 2016; 93:86-91.

25. Mendiola J, Torres-Cantero AM, Moreno-Grau JM, et al. Food intake and its relationship with semen quality: a case-control study. Fertil Steril. 2009; 91:812-818.

26. Maldonado-Carceles AB, Minguez-Alarcon L, Mendiola J, et al. Meat intake in relation to semen quality and reproductive hormone levels among young men in Spain. Br J Nutr. 2019; 121:451-460.

27. Eslamian G, Amirjannati N, Rashidkhani B, et al. Intake of food groups and idiopathic asthenozoospermia: a case-control study. Hum Reprod. 2012; 27:3328-3336.

28. Afeiche M, Williams PL, Mendiola J, et al. Dairy food intake in relation to semen quality and reproductive hormone levels among physically active young men. Hum Reprod. 2013; 28:2265-2275.

29. Afeiche MC, Bridges ND, Williams PL, et al. Dairy intake and semen quality among men attending a Fertility Clinic. Fertil Steril. 2014; 101:1280-1287.

30. Afeiche MC, Williams PL, Gaskins AJ, et al. Meat intake and reproductive parameters among young men. Epidemiology. 2014; 25:323-30.

31. Afeiche MC, Gaskins AJ, Williams PL, et al. Processed meat intake is unfavorably and fish intake favorably associated with semen quality indicators among men attending a Fertility Clinic. J Nutr. 2014; 144:1091-1098.

32. Chiu YH, Afeiche MC, Gaskins AJ, et al. Sugar-sweetened beverage intake in relation to semen quality and reproductive hormone levels in young men. Hum Reprod. 2014; 29:1575-1584.

33. Chiu YH, Afeiche MC, Gaskins AJ, et al. Fruit and vegetable intake and their pesticide residues in relation to semen quality among men from a Fertility Clinic. Hum Reprod. 2015; 30:1342-1351.

34. Gaskins AJ, Chavarro JE. Diet and fertility: a review. Am J Obstet Gynecol. 2018; 218:379-389.

35. Chavarro JE, Toth TL, Sadio SM, Hauser R. Soy food and isoflavone intake in relation to semen quality parameters among men from an inFertility Clinic. Hum Reprod. 2008; 23:2584-2590.

36. Mínguez-Alarcón L, Afeiche MC, Chiu YH, et al. Male soy food intake was not associated with in vitro fertilization outcomes among couples attending a fertility center. Andrology. 2015; 3:702-708.

37. Attaman JA, Toth TL, Furtado J, et al. Dietary fat and semen quality among men attending a fertility clinic. Hum Reprod. 2012; 27:1466-74.

38. Jensen TK, Heitmann BL, Blomberg Jensen M, et al. High dietary intake of saturated fat is associated with reduced semen quality among 701 young Danish men from the general population. Am J Clin Nutr. 2013; 97:411-418.

39. Chavarro JE, Mínguez-Alarcón L, Mendiola J, et al. Trans fatty acid intake is inversely related to total sperm count in young healthy men. Hum Reprod 2014; 29:429-440.

40. Minguez-Alarcón L, Chavarro JE, Mendiola J, et al. Fatty acid intake in relation to reproductive hormones and testicular volume among young healthy men. Asian J Androl. 2017; 19:184-190.

41. Emanuele MA, Emanuele MV. Alcohol's effect on male reproduction Alcohol Health Res World. 1998; 22:195-201.

42. Muthusami KR, Chinnaswamy P. Effect of chronic alcoholism on male fertility hormones and semen quality. Fertil Steril. 2005; 84:919-24.

43. Guthauser B, Boitrelle F, Plat A, et al. Chronic excessive alcohol 
consumption and male fertility: a case report on reversible azoospermia and a literature review.Alcohol Alcohol. 2014; 49:42-4.

44. Jensen TK, Gottschau M, Madsen JO, et al. Habitual alcohol consumption associated with reduced semen quality and changes in reproductive hormones; a cross-sectional study among 1221 young Danish men. BMJ Open. 2014; 4:e005462.

45. Ricci E, Al Beitawi S, Cipriani S, et al. Semen quality and alcohol intake: a systematic review and meta-analysis. Reprod Biomed Online. 2017; 34:38-47.

46. Nicolau P, Miralpeix E, Solà I, et al. Alcohol consumption and in vitro fertilization: a review of the literature. Gynecol Endocrinol. 2014; 30:759-63.

47. Ricci E, Viganò P, Cipriani S, et al. Coffee and caffein intake and male infertility: a systematic review. Nutr J. 2017; 16:37.

48. Richard S, Moslemi S, Sipahutar H, et al. Differential effects of glyphosate and roundup on human placental cells and aromatase. Environ Health Perspect. 2005; 113:716-20.

49. Andersson AM, Skakkebaek NE. Exposure to exogenous estrogen in food: possible impact on human development and health. Eur J Endocrinol. 1999; 140:477-85.

50. Swan SH, Liu F, Overstreet JW, et al. Semen quality of fertile US males in relation to their mothers' beef consumption during pregnancy. Hum Reprod. 2007; 22:1497-502.

51. Gao M, Li B, Yuan W, et al. Hypothetical link between infertility and genetically modified food. Recent Pat Food Nutr Agric. 2014; 6:16-22

52. Kiziler AR, Aydemir B, Onaran I, et al. High levels of cadmium and lead in seminal fluid and blood of smoking men are associated with high oxidative stress and damage in infertile subjects. Biol Trace Elem Res. 2007; 120:82-91.

53. Abu-Awwad A, Arafat T, Schmitz OJ. Simultaneous determination of nicotine, cotinine, and nicotine $N$-oxide in human plasma, semen, and sperm by LC-Orbitrap MS. Anal Bioanal Chem. 2016; 408:6473-81.

54. Antoniassi MP, Intasqui $P$, Camargo M, et al. Analysis of the functional aspects and seminal plasma proteomic profile of sperm from smokers. BJU Int. 2016; 118:814-822.

55. Künzle R, Mueller MD, Hänggi W, et al. Semen quality of male smokers and nonsmokers in infertile couples. Fertil Steril. 2003; 79:287-91.

56. Sepaniak S, Forges T, Gerard H, et al. The influence of cigarette smoking on human sperm quality and DNA fragmentation. Toxicology. 2006; 223:54-60.

57. Zitzmann $M$, Rolf $C$, Nordhoff $V$, et al. Male smokers have a decreased success rate for in vitro fertilization and intracytoplasmic sperm injection.Fertil Steril. 2003; 79 (Suppl 3):1550-4.

58. Jenkins TG, James ER, Alonso DF, et al. Cigarette smoking significantly alters sperm DNA methylation patterns. Andrology. 2017; 5:1089-1099.

59. Linschooten JO, Verhofstad N, Gutzkow K, et al. Paternal lifestyle as a potential source of germline mutations transmitted to offspring. FASEB J. 2013; 27:2873-9.

60. Nahas GG, Frick HC, Lattimer JK, et al. Pharmacokinetics of THC in brain and testis, male gametotoxicity and premature apoptosis of spermatozoa. Hum Psychopharmacol. 2002; 17:103-13.

61. du Plessis SS, Agarwal A, Syriac A. Marijuana, phytocannabinoids, the endocannabinoid system, and male fertility. J Assist Reprod Genet. 2015; 32:1575-88.
62. Gundersen TD, Jørgensen N, Andersson AM, et al. Association between use of marijuana and male reproductive hormones and semen quality: a study among 1,215 healthy young men. Am J Epidemiol. 2015; 182:473-81.

63. Dupont C, Faure C, Sermondade N, et al. Obesity leads to higher risk of sperm DNA damage in infertile patients. Asian J Androl. 2013; 15:622-5.

64. Kahn BE, Brannigan RE Obesity and male infertility Curr Opin Urol. 2017; 27:441-445.

65. Calderón B, Gómez-Martín JM, Vega-Piñero B, et al. Prevalence of male secondary hypogonadism in moderate to severe obesity and its relationship with insulin resistance and excess body weight. Andrology. 2016; 4:62-7.

66. Safarinejad MR. The effect of coenzyme Q10 supplementation on partner pregnancy rate in infertile men with idiopathic oligoasthenoteratozoospermia: An open-label prospective study. Int Urol Nephrol. 2012; 44:689-700.

67. Safarinejad MR. Efficacy of coenzyme Q10 on semen parameters, sperm function and reproductive hormones in infertile men. $J$ Urol. 2009; 182:237-48.

68. Safarinejad MR, Safarinejad S, Shafiei N, Safarinejad S. Effects of the reduced form of coenzyme 210 (ubiquinol) on semen parameters in men with idiopathic infertility: a double-blind, placebo controlled, randomized study. J Urol. 2012; 188:526-31.

69. Wang YX, Yang SW, Qu CB, et al. L-carnitine: safe and effective for asthenozoospermia. Zhonghua Nan Ke Xue. 2010; 16:420-2.

70. Balercia G, Regoli F, Armeni T, et al. Placebo-controlled doubleblind randomized trial on the use of L-carnitine, L-acetylcarnitine, or combined L-carnitine and L-acetylcarnitine in men with idiopathic asthenozoospermia. Fertil Steril. 2005; 84:662-71.

71. Banihani S, Agarwal A, Sharma R, Bayachou M. Cryoprotective effect of L-carnitine on motility, vitality and DNA oxidation of human spermatozoa. Andrologia. 2014; 46:637-41.

72. Wu ZM, Lu X, Wang YW, et al. Short-term medication of L-carnitine before intracytoplasmic sperm injection for infertile men with oligoasthenozoospermia. Zhonghua Nan Ke Xue. 2012; 18:253-6.

73. Cheng JB, Zhu J, Ni F, Jiang H. L-carnitine combined with coenzyme Q10 for idiopathic oligoasthenozoospermia: A doubleblind randomized controlled trial. Zhonghua Nan Ke Xue. 2018; 24:33-38.

74. Thérond P, Auger J, Legrand A, Jouannet P. alpha-Tocopherol in human spermatozoa and seminal plasma: Relationships with motility, antioxidant enzymes and leukocytes. Mol Hum Reprod. $1996 ; 2: 739-44$

75. Omu AE, Fatinikun T, Mannazhath N, Abraham S. Significance of simultaneous determination of serum and seminal plasma alphatocopherol and retinol in infertile men by high-performance liquid chromatography. Andrologia. 1999; 31:347-54.

76. Chen XF, Li Z, Ping P, et al. Efficacy of natural vitamin E on oligospermia and asthenospermia: a prospective multi-centered randomized controlled study of 106 cases. Zhonghua Nan Ke Xue. 2012; 18:428-31.

77. Chia SE, Ong CN, Chua LH, et al. Comparison of zinc concentrations in blood and seminal plasma and the various sperm parameters between fertile and infertile men. J Androl. 2000; 21:53-7.

78. Raigani M, Yaghmaei B, Amirjannti N, et al. The micronutrient supplements, zinc sulphate and folic acid, did not ameliorate sperm functional parameters in oligoasthenoteratozoospermic men. Andrologia. 2014; 46:956-62. 
79. Wong WY, Merkus HM, Thomas CM, et al. Effects of folic acid and zinc sulfate on male factor subfertility: a double-blind, randomized, placebo-controlled trial. Fertil Steril. 2002; 77:491-8.

80. Busetto GM, Agarwal A, Virmani A, et al. Effect of metabolic and antioxidant supplementation on sperm parameters in oligoastheno-teratozoospermia, with and without varicocele: A doubleblind placebo-controlled study. Andrologia. 2018; 50.

81. Steiner A, Hansen K, Diamond MP, et al. Antioxidants in the treatment of male factor infertility: Results from the double blind, multicenter, randomized controlled Males, Antioxidants, and Infertility (MOXI) trial. Abstract Book of $34^{\text {th }}$ Annual Meeting of the European Society of Human Reproduction and Embryology (ESHRE), 1-4 July 2018 Barcelona; Human Reproduction 2018; 33 (Suppl 1):i30.
82. Ahmadi S, Bashiri R, Nadjarzadeh A. Antioxidant supplements and semen parameters:an evidence based review Int J Reprod Biomed 2016; 14:629-736.

83. Smits RM, Mackenzie-Proctor R, Yazdani A, et al. Antioxidants for male subfertility. Cochrane Database Syst Rev. 2019; 3:CD007411.

84. Buhling $K$, Schumacher A, Eulenburg CZ, Laakmann E. Influence of oral vitamin and mineral supplementation on male infertility: a meta-analysis and systematic review. Reprod Biomed Online. 2019; 39:269-279.

85. Hussain SA, Hameed A, Nasir F, et al. Evaluation of the spermatogenic activity of polyherbal formulation in oligospermic males. BioMed Research International 2018; 2018:2070895.

\section{Correspondence}

Mahmoud Benatta

benatta.mahmoud@gmail.com

Dept. of Urology, Djilali Lyabes University Hospital, Sidi Bel Abbes/Algeria

Redha Kettache

kettacher@gmail.com

Dept. of Urology, EPH Bachir Bennacer, Biskra/Algeria

Noor Buchholz (Corresponding Author)

scientific-office@u-merge.com

noor.buchholz@gmail.com

U-merge Scientific Office 21 Athens/Greece

Alberto Trinchieri

alberto.trinchieri@gmail.com

U-merge Scientific Office 